\title{
ANALISIS KEBUTUHAN PENDIDIKAN AGAMA KRISTEN DALAM MENUMBUHKAN MORAL KRISTIANI ANAK USIA DINI
}

\author{
Hisardo Sitorus \\ Prodi Pendidikan Kristen Anak Usia Dini, IAKN Tarutung
}

\begin{abstract}
This study aims to analyze the needs of Christian religious education in fostering early Christian morals. This research was concuded at the early childhood education programs Intitut of Sipoholon sub-District North Tapanuli regency in 2018. The object of research is the teachers of Sipoholon. Earned value of $X$ overall analycis of the needs for Christian religious education in fostering the children of early childhood education programs in Sipoholon sub- district, North Tapanuli regency in 2018 is 3,07 and this value is in the good category. The result of the data calculation are on a scale 2,60-3,59. That means that teacher have tried to poster chidrens morality through Christian religious education. But in some teaching the teaher has not maximally known the importance Christian education in fostering Christian morality in early childhood.
\end{abstract}

Keywords: Christian religious education, Christian moral of kids.

\begin{abstract}
ABSTRAK
Penelitian ini bertujuan untuk menganalisis kebutuhan Pendidikan Agama Kristen dalam Menumbuhkan Moral Kristiani Anak Usia Dini. Penelitian ini dilaksanakan di Lembaga PAUD Se-Kecamatan Sipoholon Kabupaten Tapanuli Utara Tahun 2018, yang menjadi objek penelitian ini adalah guru-guru PAUD se-Kecamatan Sipoholon Kabupaten Tapanuli Utara. Diperoleh nilai $\bar{X}$ keseluruhan Analisis Kebutuhan Pendidikan Agama Kristen dalam Menumbuhkan Moral Kristiani Anak PAUD Se- Kecamatan Sipoholon Kabupaten Tapanuli Utara Tahun 2018 adalah 3,07 dan nilai ini berada pada kategori baik, hasil perhitungan data berada pada skala 2,60-3,59 berarti hipotesa diterima. Hal tersebut memperlihatkan bahwa guru sudah berupaya menumbuhkan moralitas anak melalui pendidikan Agama Kristen. Namun pada sebahagian pengajaran guru belum maksimal mengetahui pentingnya Pendidikan Agama Kristen dalam menumbuhkan moralitas kristiani anak usia dini.
\end{abstract}

Kata Kunci: Pendidikan agama Kristen, moral kristiani anak usia dini

\section{PENDAHULUAN}

Pendidikan Anak Usia Dini merupakan suatu bentuk penyelenggaraan pendidikan yang menitik beratkan pada peletakan dasar ke arah pertumbuhan dan perkembangan: moral dan agama, fisik motorik, kognitif, bahasa, sosialemosional, dan seni, sesuai dengan keunikan tahap-tahap perkembangan kelompok usia yang dilalui oleh anak usia dini. Moral Kristiani adalah sikap

72 Korespondensi mengenai artikel dapat dilakukan kepada: Hisardo Sitorus, Institut Agama Kristen Negeri Tarutung, J1. Raya Tarutung-Siborong KM 11, Silangkitang, Sipoholon, Tapanuli Utara (22452), Indonesia

E-mail Corresponding: hisardositorus@yahoo.com 
percaya kepada Tuhan yang bertumbuh melalui ajaran tentang Firman Tuhan, pengenalan akan Tuhan dan segala ciptaan-Nya. Melalui pengajaran tersebut maka anak-anak dapat mengalami pertumbuhan iman dan selalu semangat dan pengertian bahwa Tuhan selalu memelihara kehidupan mereka.

Pendidikan Agama Kristen merupakan proses pengajaran dan pembelajaran berdasarkan alkitab, berpusatkan pada Kristus dan bergantung pada kuasa Roh Kudus. Demikian juga pendidikan Kristen yang diberikan kepada anak usia dini hendaknya dapat membantu pembentukan moral Kristiani anak. Anakanak merupakan anugrah Tuhan, mereka adalah generasi penerus bagi sebuah negara, keberhasilan mereka dimasa mendatang dipengaruhi pembentukan dan perkembangan sejak usia dini. Konsep pengenalan nilai-nilai kristiani harus diperkenalkan kepada mereka, sejak dini mereka diperkenalkan Injil, pengajaran Alkitab maupun pengenalan akan Allah. Hal tersebut dapat dilakukan melalui pengajaran berdoa, bernyanyi dan memperdengarkan dan mengajarkan Firman Tuhan. Untuk menjangkau dan membawa anak kepada Tuhan Yesus serta mengajarkan Firman Tuhan dan mengubah kehidupan mereka menjadi pengikut Yesus yang bertumbuh dalam kerohanian yang penuh dengan pengharapan akan janji keselamatan.

Pembentukan moral Kristiani manusia lebih tepat dilakukan pada usia dini karena mereka lebih cepat menerima, meyakini ajaran tentang iman dan percaya kepada Tuhan, sedangkan bagi kelompok usia remaja dan dewasa sudah sulit menerima Firman Tuhan sebab mereka sudah berorientasi pada kemampuan berpikir rasional. Pembentukan moral pada usia remaja dan dewasa kemungkinan besar akan mengalami kegagalan, kekecewaan karena dengan berpikir rasional mereka akan menolak ajaran tersebut dengan beranggapan ajaran moral spritual hanya cerita sandiwara yang membatasi ruang dan kebebasan duniawi. Sehingga mereka tetap menjadi individu yang membangkang, kelompok yang membangkang, melakukan pemberontakan pada pemerintahan yang berdaulat, menjadi anggota teroris. Melakukan pemberontakan pada ajaran dan aturan yang ditetapkan di manapun dia berada: baik di keluarga, di lingkungan masyarakat, di sekolah/ kampus, di gereja dan lain sebagainya. Oleh karena hal tersebutlah anak merupakan bagian yang sangat penting dalam sebuah negara, pihak yang terlibat dalam mengajarkan Firman Tuhan bagi anak usia dini adalah guru pendidikan Kristen.

Guru merupakan orang yang sesungguhnya bertanggung jawab atas pelayanan kepada anak dan sekaligus menjadi rekan kerja orangtua dalam membina, mendidik anak sesuai ajaran Tuhan. Secara formal apa yang diharapkan dari pendidikan Agama Kristen adalah memperkenalkan, mengembangkan dan mempraktikkan keehidupan orang Kristen sesuai dengan iman Kristen (Laheba 2007:5). Mengingat pentingnya Pendidikan Agama Kristen ini, sejak dini seharusnya pendidikan Kristen sudah menjadi agenda pembelajaran

73 | Analisis Kebutuhan Pendidikan Agama Kristen dalam Menumbuhkan Moral... Sitorus, Hisardo Jurnal Christian Humanioran | http://e-journal.iakntarutung.ac.id/index.php/humaniora 
di sekolah-sekolah Pendidikan Anak Usia Dini (PAUD). Namun sejauh ini pengamatan penulis mengungkapkan bahwa: (a) belum tersedianya bahan ajar pendidikan Kristen anak usia dini sebagai pedoman mengajar guru; (b) belum tersedianya guru pendidikan Kristen anak usia dini yang profesional; (c) belum tersedianya kurikulum, silabus sebagai acuan pengajaran; (d) pengajaran yang berorientasi kognitif; dan (e) kecamatan Sipoholon Kabupaten Tapanuli Utara adalah masyarakat yang hampir keseluruhan beragama Kristen oleh karena itu pendidikan Kristen anak usia dini merupakan bidang ilmu yang urgen diterapkan.

Hal di atas menjadi latar belakang masalah dan menjadi sebuah sumber pertanyaan sebab bagaimana mungkin anak-anak dapat menerima Firman Tuhan dan berperilaku sesuai dengan kehendak Tuhan sementara guru tidak menyampaikan pengajaran Firman Tuhan? Dan bagaimana mungkin pembelajaran Kristen terlaksana dengan baik apabila guru tidak memiliki bahan ajar sebagai acuan yang baik? Kemampuan guru merupakan kemampuan yang ditetapkan dan diberikan Allah melalui proses belajar guru tersebut, sama seperti seorang ahli bangunan yang meletakkan dasar yang kokoh tentang Yesus Kristus kepada anak-anak sebagai bekal masa depan yang gemilang.

Menilik berbagai masalah di atas dipahami bahwa masalah dalam penyelenggaraan PAUD sebahagian besar justru timbul dari dalam lembaga itu sendiri. Hal inilah yang mendasari pelaksanaan penelitian ini dengan Judul: "Analisis Kebutuhan Pendidikan Agama Kristen dalam Menumbuhkan Moral Kristiani Anak Usia Dini Se- Kecamatan Sipoholon Kabupaten Tapanuli Utara Tahun 2018". Adapun permasalahan penelitian dibatasan pada: Analisis Kebutuhan Pendidikan Agama Kristen dalam Menumbuhkan Moral Kristiani Anak Usia Dini. Sedangkan untuk rumusan masalah yaitu: bagaimana Kebutuhan Pendidikan Agama Kristen dalam Menumbuhkan Moral Kristiani Anak Usia Dini Se- Kecamatan Sipoholon Kabupaten Tapanuli Utara Tahun 2018”. Dengan demikian, tujuan penelitian ini adalah untuk mengetahui Kebutuhan Pendidikan Agama Kristen dalam Menumbuhkan Moral Kristiani Anak Usia Dini SeKecamatan Sipoholon Kabupaten Tapanuli Utara Tahun 2018”.

\section{METODE}

Penelitian ini dilakukan dengan menggunakan metode penelitian kuantitatif deskriptif yang bersifat korelasional. Metode ini digunakan untuk meneliti populasi atau sampel yang telah ditentukan. Pengumpulan data menggunakan instrument penelitian berupa angket.

\section{HASIL DAN PEMBAHASAN}

\section{Moral Kristiani}

Dalam pembahaan penelitian ini dijelaskan bahwa pengertian moral adalah ajaran tentang tingkah laku, perbuatan baik yang terdapat pada tempat dan kebiasaan tertentu. Hal ini sejalan dengan Brownlee (1996:147) mengatakan 
moral adalah sopan santun berbahasa. Sementara Suseno (1986:141) mengatakan moral adalah kejujuran dan kerendahan hati. Oleh karena itu dapat dikatakan bahwa seseorang anak yang bermoral jika yang bersangkutan dapat memperlihatkan perbuatan baik, sopan, santun berbahasa, jujur dan rendah hati. Selanjutnya pengertian moral Kristiani berkaitan dengan kehidupan iman dan kepercayaan umat Kristen. Apa yang mereka lakukan adalah bentuk nyata sesuai iman dan kepercayaannya. Secara lebih konkret Ganss yang dikutib Mc Grath (2007:5) mengatakan bahwa moralitas Kristen adalah pengalaman yang dihayati, suatu upaya untuk mengaplikasikan berbagai unsur yang relevan dalam iman Kristen yang dapat membimbing perempuan maupun laki-laki menuju pertumbuhan spiritual mereka, menuju proporsional menjadi sukacita dan pengertian yang semakin besar.

Pembentukan merupakan suatu pekerjaan atau usaha orang-orang yang berpengetahuan dan bertanggung jawab memupuk suatu kesadaran untuk mencapai suatu tujuan yang diharapkan. Pembentukan sangat dipengaruhi oleh berbagai hal seperti: tenaga, sarana dan prasarana, biaya dan juga tidak terlepas dari dukungan dan dorongan. Jika pendapat tersebut di atas dipadukan menjadi pembentukan moral Kristiani maka makna yang dikandung adalah upaya menciptakan, menjadikan manusia memiliki pengetahuan dan sikap yang baik sesuai dengan kehendak Tuhan serta memiliki pengalaman yang dihayati menyangkut bagaimana orang secara penuh meraih serta memiliki hubungan yang setia dengan Tuhan dalam kehidupan kristen secara nyata.

\section{Pengertian dan Tujuan Pendidikan Anak Usia Dini}

Pendidikan Anak Usia Dini (PAUD) pada hakikatnya adalah pendidikan yang diselenggarakan dengan tujuan untuk memfasilitasi pertumbuhan dan perkembangan anak secara menyeluruh atau menekankan pada perkembangan seluruh aspek kepribadian anak. Oleh karena itu PAUD memberi kesempatan bagi anak untuk mengembangkan kepribadian dan potensi secara maksimal, atas dasar ini lembaga PAUD perlu menyediakan berbagai kegiatan yang dapat mengembangkan berbagai aspek perkembangan seperti perkembangan moral, kognitif, bahasa, sosial, emosional, fisik dan motorik. Secara institusional, Pendidikan Anak Usia Dini juga dapat diartikan sebagai salah satu bentuk penyelenggaraan pendidikan yang menitikberatkan pada peletakan dasar ke arah pertumbuhan dan perkembangan baik kordinasi motorik halus dan kasar, kecerdasan emosional, kecerdasan jamak (multiple inteligences) dan kecerdasan spritual (Suyadi, 2017:22).

Secara Yuridis dalam Undang-Undang Nomor 20 Tahun 2003 tentang Sistem Pendidikan Nasional Pasal 1 ayat 14 dinyatakan bahwa Pendidikan Anak Usia Dini adalah suatu upaya yang ditujukan kepada anak sejak lahir sampai dengan usia enam tahun yang dilakukan dengan pemberian rangsangan pendidikan untuk membantu perkembangan pertumbuhan jasmani dan rohani agar

75 | Analisis Kebutuhan Pendidikan Agama Kristen dalam Menumbuhkan Moral... Sitorus, Hisardo Jurnal Christian Humanioran | http://e-journal.iakntarutung.ac.id/index.php/humaniora 
anak memiliki kesiapan dalam memasuki pendidikan lebih lanjut. Selanjutnya pada Pasal 28 dinyatakan tentang Pendidikan Anak Usia Dini bahwa: Pertama, Pendidikan Anak Usia Dini diselenggarakan sebelum jenjang pendidikan dasar. Kedua, Pendidikan Anak Usia Dini dapat dilaksanakan melalui jalur pendidikan formal seperti TK, informal seperti pendidikan keluarga dan atau non-formal. Seperti KB atau Play Group dan lain sebagainya. Pembentukan perilaku perilaku berjalan sering dengan proses penyesuaian diri anak dengan lingkungan sosialnya yang mulai beragam. Anak yang awalnya hanya mementingkan kebutuhan dan keinginan sendiri dengan ketergantungan yang kuat pada keluarga, secara bertahap beralih ketingkat kemandirian yang tinggi (Izzaty, 2017:1).

Secara umum tujuan Pendidikan Anak Usia Dini adalah memberikan stimulus atau rangsangan bagi perkembangan potensi anak yang beriman dan bertaqwa kepada Tuhan Yang Maha Esa, berahlak mulia, sehat, berilmu, cakap, mandiri, kreatif, inivatif, percaya diri dan menjadi warga negara yang demokratis dan bertanggung jawab (Puskur, Depdiknas 2007 dalam Suyadi 2017: 24). Berdasarkan pendapat di atas dapat dipahami bahwa Pendidikan Anak Usia Dini baik secara institusional dan yuridis bertujuan untuk memberi rangsangan, membantu pertumbuhan jasmani dan rohani anak.

\section{Kompetensi Moral Kristiani Anak Usia Dini}

Meskipun moral kristiani lebih nyata dilihat dalam keseharian orang dewasa namun pembentukannya dimulai dari usia dini dan diperoleh melalui pembelajaran. Menurut Elisabeth (2010:59) bahwa menu pembelajaran Anak Usia Dini pada kelompok 4-6 tahun pada pengembangan spritual serta kompetensi dan hasil belajar yang ingin dicapai adalah kemampuan melakukan ibadah, mengenal dan percaya akan ciptaan Tuhan dan mencintai sesama.

Adapun Indikator kemampuan yang dimaksud seperti di atas adalah: (a) menyanyikan lagu-lagu rohani; (b) berdoa sebelum dan sesudah melakukan kegiatan dengan sikap berdoa yang benar; (c) mendengarkan cerita-cerita dan tokoh-tokoh dalam alkitab; (d) membedakan ciptaan Tuhan dan buatan manusia; (e) menyayangi orang tua, pembantu, orang di sekeliling serta teman dengan bapak ibu guru di sekolah dan di rumah, menyayangi binatang dan tanaman ciptaan Tuhan; (f) mengenal dan memahami sifat- sifat Yesus; (g) merasakan/ ditujukan rasa sayang, cinta kasih melalui belaian/rangkulan; (h) selalu mengucapkan terimakasih setelah menerima sesuatu; (i) mengucapkan salam; (j) mengucapkan kata-kata santun seperti minta maaf dan minta tolong; (k) menghargai teman dan tidak melaksanakan kehendak; (l) menolong teman dan orang dewasa; (m) menunjukkan perilaku atas dasar keyakinan adanya Tuhan yang maha tahu dan mendengar, dan sebagainya.

Selanjutnya menurut Lie Paulus (2009:114) bahwa perkembangan moral anak usia 5-6 tahun adalah: (a) anak belum mengenal rasa hormat pada tatanan moral; (b) anak belajar tanggap terhadap aturan budaya dan penilaian baik buruk

76 | Analisis Kebutuhan Pendidikan Agama Kristen dalam Menumbuhkan Moral... Sitorus, Hisardo Jurnal Christian Humanioran | http://e-journal.iakntarutung.ac.id/index.php/humaniora 
melalui akibat fisik yang diterima sesuai perbuatannya; (c) perbuatan dinilainya benar apabila memuaskan kebutuhan pribadinya dan memuaskan orang lain apabila dikassihi; (d) ia menilai hubungan dengan wajar sebagai pembagian sama rata (secara fisik dan pragmatis). Ia mengenal balas jasa secara setimpal. Dia belum mengenal loyalitas, ungkapan terimakasih atau keadilan; (e) anak sudah dapat mengenal anggota keluarganya.

Lebih lanjut Asmawati 2014:57 mengatakan bahwa nilai-nilai agama dan moral pada Anak Usia Dini mencakup:

(1) mengenal Tuhan melalui agama yang dianutnya melalui capaian perkembangan yaitu mengenal ciptaan Tuhan dan menyayangi ciptaan, mengenal bermacam-macam agama, mengenal lagu keagamaan yang sederhana seperti menyebutkan ciptaan- ciptaan Tuhan misalnya, manusia, bumi, langit, tanaman dan hewan, memberi makan hewan, menyiram tanaman, menyayangi sesama, menyebutkan hari besar agama, menyanyikan lagu keagamaan yang sederhana, menyebutkan hari besar agama;

(2) Meniru gerakan beribadah, mengenal tempat-tempat ibadah, mengenal waktu-waktu beribadah;

(3) Mengucapkan doa sebelum dan sesudah makan serta berdoa sebelum dan sesudah melakukan kegiatan;

(4) Mengenal perilaku baik sopan dan buruk dalam berpakaian, berbicara, bertingkah laku terhadap sesama. Berbicara yang baik dengan teman, orang dewasa, berpakaian yang rapi di rumah, di sekolah, tidak mengganggu teman, meminta tolong, mudah bergaul;

(5) Mengucapkan salam dan membalas salam dengan cara membiasakan diri mengucapkan dan membalas salam.

\section{Ciri-ciri Anak dalam Pertumbuhan Moral Kristen}

Dalam kehidupan moral anak, banyak hal yang harus diperhatikan oleh orangtua, terutama dalam mengenal atau mengetahui ciri anak yang sudah memiliki atau perkembangan moral Kristen. Menurut Virgil (2012:36) ada sepuluh ciri-ciri anak yang sudah memiliki spiritual yang baik:

(1) Rajin Berdoa

Anak yang rajin berdoa bukan hanya akan mendoakan keluarganya sendiri, tetapi juga untuk para gereja, para hamba Tuhan, pekerjaan Tuhan, teman sekolah, tetangga, dan juga yang lain sebagainya. Dimana si anak akan mengalami kesungguhan hidup dengan Allah

(2) Rajin Baca Alkitab

Dalam membimbing anak agar rajin baca Alkitab, maka orangtua perlu mencari ayat-ayat alkitab sebagai pendukung untuk dibacakan dalam kebaktian keluarga setiap harinya.

(3) Rajin Menyanyikan Lagu Rohani

77 | Analisis Kebutuhan Pendidikan Agama Kristen dalam Menumbuhkan Moral... Sitorus, Hisardo Jurnal Christian Humanioran | http://e-journal.iakntarutung.ac.id/index.php/humaniora 
Salah satu kreasi mengajar yang paling biasa dipakai dalam mengajar anak adalah dengan nyanyian atau musik, anak-anak senang menyanyi, dan dengan bernyanyi tiap anak sekaligus dapat mengambil peran aktif dan kata-kata dalam setiap nyanyian akan meresap kedalam hati anak-anak itu, sehingga menjadi bagian yang tetap dari hidup kepercayaan mereka.

(4) Rajin ke Sekolah Minggu

Setiap orangtua terpanggil untuk ikut ambil bagian dalam membentuk anak-anak yang dipercayakan Tuhan kepada mereka. Ini merupakan tanggungjawab yang sangat besar. Pelayanan anak atau sekolah minggu tidak semata-mata dibentuk untuk mendidik anak-anak manis yang mempunyai sikap baik budi itu bukan tujuan utama Tuhan bagi anak-anak. Tetapi yang terutama mereka harus berjumpa secara pribadi dengan Tuhan Yesus Kristus.

(5) Rajin ke Gereja

Bagi orangtua kristen, gereja merupakan bagian penting yang tidak bisa dilewatkan dalam proses pertumbuhan rohani anak. Konsep dan teori tentang pertumbuhan rohani anak memang sudah banyak dipahami dan diterapkan gereja. Gereja adalah suatu lembaga paedagogis, yang bertanggungjawab untuk menyelenggarakan kegiatan pendidikan terhadap pertumbuhan rohani anak. Dengan demikian, tugas yang makin mendesak bagi orangtua untuk memberikan motivasi kepada Anak-anak untuk rajin ke gereja.

(6) Rajin Memberikan Persembahan

Memberikan persembahan sebagai wujud cintakasih anak terhadap pekerjaan Tuhan. Pertumbuhan rohani melalui pemberian persembahan akan menjadi dasar perumbuhan rohani anak untuk dapat mengenal kebenaran Alkitab. Apabila anak rajin memberikan persembahan mengakibatkan, generasi selanjutnya juga rajin memberikan persembahan, karena anak sebagai penerus dan pemimpin generasi yang akan datang. Tidak bisa disangkal bahwa anak rajin memberi persembahan sebagai sumbangsih bagi operasional pekerjaan Tuhan dimuka bumi ini. Oleh karena itu sebagai orangtua Kristen perlu mendorong anak-anak dan memberi perhatian besar kepada mereka untuk dapat rajin memberikan persembahan.

(7) Rajin Mengikuti Kegiatan Rohani

Kegiatan kelompok rohani sebagai persekutuan anak-anak untuk saling menghargai, menghormati satu sama lain terlebih kepada pemimpin. Kegiatan kelompok rohani sebagai persekutuan yang baik dengan Tuhan akan turut menentukan persekutuan dengan sesama.

(8) Rajin Baca-baca Buku Rohani

78 | Analisis Kebutuhan Pendidikan Agama Kristen dalam Menumbuhkan Moral... Sitorus, Hisardo Jurnal Christian Humanioran | http://e-journal.iakntarutung.ac.id/index.php/humaniora 
Membaca buku rohani adalah suatu kebiasaan yang baik bagi pertumbuhan rohani anak, dimana anak akan memperoleh pengetahuan alkitab yang memungkinkan anak hidup bergantung dan berpusat pada Kristus. Oleh sebab itu, sebagai orangtua Krisen memotivasikan anak agar memiliki potensi untuk rajin membaca buku-buku rohani.

(9) Rajin Berperilaku Baik

Masa anak-anak adalah masa pembentukan yang paling mudah. Dunia anak-anak adalah dunia kepolosan karena hal itu mereka masih jujur dan bersih, belum banyak dicemari oleh dosa yang jahat. Kebiasaan-kebiasaan buruk belum terbentuk. Oleh karena itu jika anak mendapat pengajaran yang baik dari orangtua mereka di masa kecil maka hidup dimasa dewasanya akan jauh lebih mudah untuk dibentuk dan perilaku yang baik selalu mewarnai kehidupan mereka.

(10) Rajin Bersaksi dengan Yesus

Orangtua Krisen yang mengutamakan Tuhan akan menyadari bahwa bersaksi tentang Kristus adalah pekerjan yang mulia dan suci. Oleh karena itu orangtua tidak sekali-sekali mengabaikan bersaksi tentang Kritus. Dengan demikian orangtua kristen semestinya mendorong anak-anak mereka untuk tetap setia bersaksi tentang kristus kepada orang yang belum mengenalnnya terutama dalam perkembangan dan pertumbuhan rohani anak.

Dari pendapat di atas dipahami bahwa anak perlu dibentuk kesadaran moralnya agar anak tidak mudah terombang-ambing oleh pengaruh lingkungan sekitarnya. Dengan memiliki moral yang baik anak memiliki pegangan hidup dan semangat yang baik.

\section{Prinsip Prinsip Pelaksanaan Pendidikan Kristen Anak Usia Dini}

Pendidikan kristen adalah istilah yang merujuk pada usaha mendidik dan mengajar anak didik di sekolah, gereja, organisasi Kristen maupun dalam keluarga dan tempat-tempat dimana untuk mengajarkan firman Allah. Werner yang dikutip oleh Kristianto (2008:4) mengemukakan bahwa: "Pendidikan Kristen adalah proses pengajaran dan pembelajaran yang berlandaskan Alkitab, berpusat pada Yesus Kristus, dan bergantung pada Roh Kudus, yang membimbing setiap pribadi, melalui pengajaran masa kini ke arah pengenalan dan pengalaman rencana dan kehendak Allah melalui Kristus dan setiap aspek kehidupan, dan memperlengkapi mereka bagi pelayan yang efektif yang berpusat pada Kristus Sang guru Agung dan perintah yang mendewasakan para murid.

Pendidikan Kristen merupakan proses yang sengaja dengan mengadakan ajaran kekristenan serta dogma kristen untuk membawa pengenalan kehendak Allah yang berpusat pada Kristus. Menurut Elisabeth (2010:9) bahwa prinsip pelaksanaan program pendidikan anak usia dini harus mengacu pada prinsip umum yang terkandung dalam konvensi hak anak, yaitu :

79 | Analisis Kebutuhan Pendidikan Agama Kristen dalam Menumbuhkan Moral... Sitorus, Hisardo

Jurnal Christian Humanioran | http://e-journal.iakntarutung.ac.id/index.php/humaniora 
1. Non Diskriminasi, dimana semua anak dapat mengecap pendidikan usia dini tanpa membedakan suku bangsa, jenis kelamin, bahasa, agama, tingkat sosial serta kebutuhan khusus setiap anak.

2. Dilakukan demi kebaikan terbaik untuk anak (the best interest of the child), bentuk pengajaran, kurikulum yang diberikan harus disesuaikan dengan tingkat perkembangan kognitif, emosional, konteks sosial budaya dimana anak-anak hidup.

3. Mengakui adanya hak hidup, kelangsungan hidup,dan perkembangan yang sudah melekat pada anak.

4. Penghargaan terhadap pendapat anak (respect for the views of child), pendapat anak terutama yang menyangkut kehidupannya perlu mendapat perhatian dan tanggapan.

Selanjutnya Elisabeth (2010:10) berpendapat bahwa: Pendidikan anak usia dini yang diterapkan dalam pembelajaran Kristen didasarkan atas prinsip-prinsip berikut :

1. Berorientasi pada kebutuhan anak.

Kegiatan belajar harus selalu ditunjukan pada pemenuhan anak secara individu, karena anak merupakan individu yang unik, maka masing-masing anak memiliki kebutuhan rangsangan yang berbeda pula.

2. Kegiatan belajar dilakukan melalui bermain.

Bermain merupakan Pendekatan dalam mengelola kegiatan belajar anak, dengan menetapkan metode, strategi, sarana dan media belajar yang merangsang anak untuk melakukan eksplorasi, menemukan dan menggunakan benda-benda yang ada di sekitarnya.

3. Merangsang munculnya kreativitas dan inovatif.

Kreativitas dan inovatif tercermin melalui kegiatan yang membuat anak tertarik, fokus, serius, dan konsentrasi.

4. Menyediakan lingkungan yang mendukung proses belajar.

Lingkungan harus diciptakan menjadi lingkungan yang menarik dan menyenangkan bagi anak selama mereka bermain.

5. Mengembangkan kecakapan hidup anak.

Kecakapan hidup diarahkan untuk membantu anak menjadi mandiri, disiplin, mampu bersosialisasi, dan memiliki keterampilan dasar yang berguna bagi kehidupan kelak.

6. Menggunakan berbagai sumber dan media belajar yang ada di lingkungan sekitar.

7. Dilakukan dengan mengacu pada prinsip perkembangan anak.

8. Rangcangan pendidikan mencakup semua aspek perkembangan.

Berdasarkan pandangan tersebut di atas pelayanan pendidikan Anak Usia

Dini tersebut tidak boleh memihak, benar-benar menjawab kebutuhan anak, berorientasi pada kebaikan anak, bermain, mengembangkan kecakapan, 
dilengkapi dengan sarana bermain dengan demikian anak-anak dapat bertumbuh dan berkembang baik maral dan sprituanya.

Menurut Anthony dan Elisabeth Capon yang dikutip Simamora dkk (2011:13), menyatakan bahwa "anak adalah pribadi yang matang dalam pandangannya sendiri. Artinya anak memiliki potensi untuk mengerti, memahami, namun sesuai dengan tingkat perkembangannya. Karena itu, mereka membutuhkan penjelasan berita injil yang sesuai dengan tingkat pengertiannya, sejajar dengan kemampuan bahasa yang dimilikinya. Atas dasar itulah mengapa Yesus melarang murid-murid-Nya, karena menghambat anak-anak yang sedini mungkin ingin datang kepada Yesus, untuk memiliki relasi akrab dengan Dia. Dalam meyampaikan materi untuk anak harus menggunakan cara atau metode yang sesuai dengan tahapan usia. Biasanya dengan bercerita sambil bermaian.

Menurut Lie Paulus (2002:1) apa dan bagaimana anak aktif belajar? Dapat diterapkan bercerita dan membaca Alkitab, oleh karena itu guru harus menguasai berbagai cerita dan kisah yang terdapat dalam Alkitab. Berdasarkan pendapat tersebut penulis memahami bahwa Pendidikan Kristen untuk anak usia dini adalah usaha yang dilakukan untuk membentuk moral spritual mereka dan membekali mereka dengan moral spritual sehingga anak mengerti dan memahami serta mengaplikasikan hidup yang penuh kasih di dalam kehidupannya seharihari.

\section{Diagram Nilai Rata-rata dan Kriteria Interpretasi}

Melalui diagram di bawah ini ditunjukkan nilai rata-rata interpretasi setiap indikator

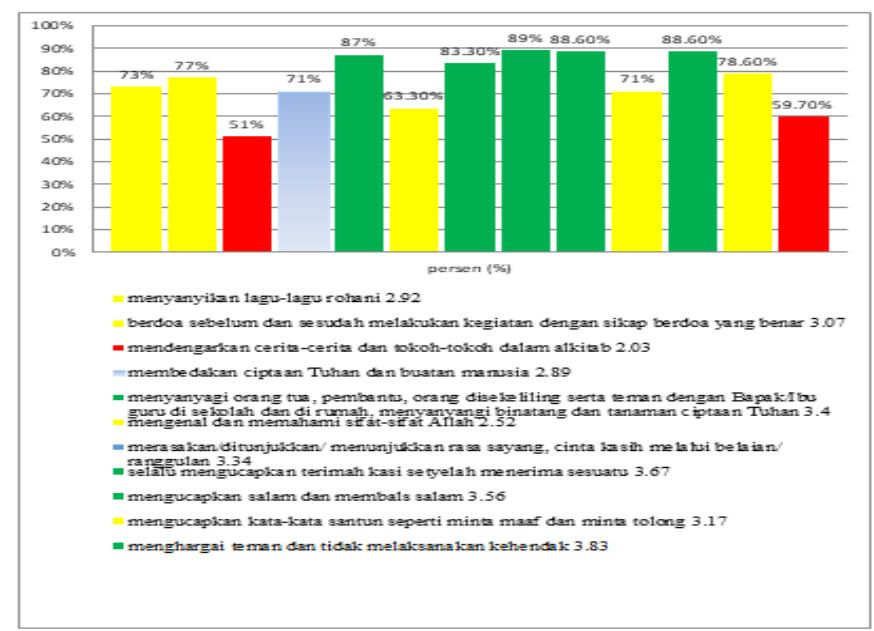

\section{Keterangan}

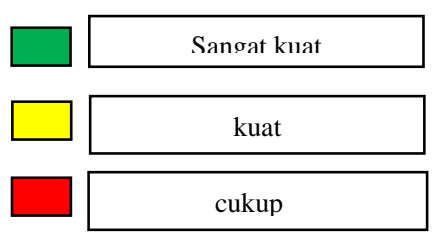

81 | Analisis Kebutuhan Pendidikan Agama Kristen dalam Menumbuhkan Moral... Sitorus, Hisardo Jurnal Christian Humanioran | http://e-journal.iakntarutung.ac.id/index.php/humaniora 


\section{PENUTUP}

Berdasarkan hasil penelitian yang ditemukan dalam penelitian ini disimpulkan melalui perhitungan rata-rata Analisis Kebutuhan Pendidikan Agama Kristen dalam Menumbuhkan Moral Kristiani Anak PAUD Se-Kecamatan Sipoholon Kabupaten Tapanuli Utara, melalui hasil perhitungan rata-rata total yang besarnya 3,07 maka hasilnya dibandingkan dengan rentangan nilai yang dikemukakan oleh Wayan Nurkanca, dan ternyata Analisis Kebutuhan Pendidikan Agama Kristen dalam Menumbuhkan Moral Kristiani Anak PAUD SeKecamatan Sipoholon Kabupaten Tapanuli Utara, dalam kategori kuat dengan rata-rata interpretasi $75,4 \%$ berada dalam kategori kuat. Melalui analisa data terdapat indikator No: 5, 7, 8, 9, 10 berada pada kriteria interpretasi yang sangat kuat dan nilai rata-rata indikator 3 dan 13 masih termasuk dalam kategori cukup.

Adapun saran berdasarkan hasil penilitian ini yaitu: (a) hendaknya guru PAUD menyadari bahwa perlu bagi mereka untuk melaksanakan pengajaran pendidikan Kristen untuk anak usia dini karena pengajaran tersebut dapat menimbulkan dampak yang begitu besar dalam aspek spritual, kognitif, dan psikomotorik sebagai gerakan perubahan dalam pribadi seseorang; (b) hendaknya guru PAUD mengerti tentang bagaimana pendidikan Kristen dapat mempengaruhi kepribadian seseorang atau kurang lebih menaruh perhatian pada pembentukan kepribadian. Pendidikan Kristen harus membawa pembentukan moral kristen sebagai tujuan masa depan anak yang berahlak mulia serta takut akan Tuhan; (c) hendaknya guru PAUD berupaya mengembangkan pendidikan Kristen untuk anak usia dini misalnya: melalui pengembangan bahan ajar, silabus, kurikulum yang sesuai dengan perkembangan anak; dan (d) hendaknya guru PAUD mengerti bahwa pendidikan Kristen adalah usaha sadar dan terencana untuk meletakkan dasar pengajaran dan pendidikan melalui mewujudkan suasana belajar dan proses pembelajaran secara aktif, membantu mengembangkan potensi mereka untuk mengalami pembentukan moralitas kristen.

\section{DAFTAR PUSTAKA}

Lembaga Alkitab Indonesia, Jakarta

Asmawati Luluk. Perencanaan Pembelajaran PAUD. Bandung: PT Remaja Rosdakarya

Brownlee Malclom, 1996. Tugas Wanita dalam Dunia Milik Tuhan, Jakarta: BPK Gunung Mulia.

Elisabeth. 2010. Pembelajaran PAK pada Anak Usia Dini. Bandung: Bima media Informasi

Izzaty Eka Rika dkk. 2017. Model Konseling Anak Usia Dini. Bandung: PT Remaja Rosdakarya

Kristianto, paulus Lilik. 2008. Prinsip dan Praktek Pendidikan Agama Kristen. Yogyakarta: Andi

82 | Analisis Kebutuhan Pendidikan Agama Kristen dalam Menumbuhkan Moral... Sitorus, Hisardo Jurnal Christian Humanioran | http://e-journal.iakntarutung.ac.id/index.php/humaniora 
Laheba, Novelina. 2007. Guruku Sahabatku, Yogjakarta: Andi

Lie, Paulus. 2002. Metode Anak Aktif dalam bercerita dan Membaca Alkitab Yogjakarta: Andi

Mc Grath, Alister. E. 2007. Spiritualitas Kristen. Medan: Bima Media.

Suryadi. 2017. Teori Pembelajaran Anak Usia Dini. Bandung: PT Remaja Rosdakarya

Suseno Frans Magnes. 1986. Kuasa dan Moral, Jakarta: Kasinus

Virgil, Jhon. 2012. Peran Orangtua Dalam Pengajaran Pendidikan Agama Kristen Terhadap Pertumbuhan Rohani Anak. Jakarta.

Simamora dkk. 2011. Pendidikan Agama Kristen Remaja. Medan. Mitra 